\title{
PENGGUNAAN BEBERAPA JENIS BAHAN ORGANIK DENGAN WAKTU APLIKASI YANG BERBEDA PADA BUDIDAYA TANAMAN SAWI (Brassica juncea L.)
}

\author{
USE OF SOME ORGANIC MATTER TYPES WITH DIFFERENT TIME APPLICATIONS ON \\ MUSTARD (Brassica juncea L.)
}

\author{
Saartje Sompotan dan Jeane S.M. Raintung*) \\ "Dosen Jurusan Budidaya Pertanian Fak. Pertanian Unsrat
}

\begin{abstract}
Research on the Use of Multiple Types of Organic Materials with Different Application Times on Mustard (Brassica juncea L.) was conducted to study the effect of organic material source interaction and application time in improving the growth and yield of mustard and obtaining organic sources of materials and timing applications to improve growth and yield of mustard. Factorial research with two factors is designed using Group Random Design. The first factor was: source of organic material (A) consisted of: $A 1=$ pig waste, $A 2=$ cattle dung, $A 3=$ rice straw. The second factor is application time $(B)$ Time: $\mathrm{B} 1=5$ days before planting seedlings (SBTB), B2 $=10$ days before planting seedlings (SBTB), B3 $=15$ days before planting seedlings (SBTB) Each experimental unit is repeated three times there were 27 pot of experiments, the variables observed were: plant height, leaf number, leaf width, leaf length and weight of wet stratum. The data were analyzed using variance analysis and if there were difference followed by Honest Real DifferenceTest at $5 \%$. The results showed that effect of interaction between source of organic matter with different application time to the number of leaves, fresh weight, content of $\mathrm{N}, \mathrm{P}$, and $\mathrm{K}$ of soil after harvesting of mustard. Plant height and leaf length is singly affected by application time. Source of organic material of cow dung and paddy straw at the time of application 10 and 15 days before planting seedlings give the best result on the number of leaves, fresh weight of mustard, $\mathrm{N}, \mathrm{P}$ and $\mathrm{K}$.
\end{abstract}

Keywords: mustard, organic matter source, application time, organic fertilizer

\section{ABSTRAK}

Penelitian Penggunaan Beberapa Jenis Bahan Organik dengan Waktu Aplikasi yang Berbeda Pada Budidaya Tanaman Sawi (Brassica juncea L.) dilakukan untuk mempelajari pengaruh interaksi sumber bahan organik dan waktu aplikasi dalam meningkatkan pertumbuhan dan hasil sawi serta memperoleh sumber bahan organik dan aplikasi waktu yang tepat dalam meningkatkan pertumbuhan dan hasil sawi. Penelitian faktorial dengan dua faktor dirancang dengan menggunakan Group Random Design. Faktor pertama adalah: sumber bahan organik $(\mathrm{A})$ terdiri dari: $\mathrm{A} 1=$ limbah babi, $\mathrm{A} 2=$ kotoran ternak, $\mathrm{A} 3=$ jerami padi. Faktor kedua adalah waktu aplikasi (B) Waktu: B1 $=5$ hari sebelum penanaman bibit (SBTB), B2 $=10$ hari sebelum penanaman bibit (SBTB), B3 $=15$ hari sebelum penanaman bibit (SBTB) Setiap unit percobaan diulang sebanyak tiga kali Ada 27 pot percobaan, variabel yang diamati adalah: tinggi tanaman, jumlah daun, lebar daun, panjang daun dan berat lapisan basah. Data dianalisis dengan menggunakan analisis varians dan jika ada perbedaan yang diikuti oleh Jujur Real DifferenceTest sebesar $5 \%$. Hasil penelitian menunjukkan bahwa pengaruh interaksi antara sumber bahan organik dengan waktu penerapan yang berbeda terhadap jumlah daun, bobot segar, kadar N, P, dan $\mathrm{K}$ tanah setelah pemanenan sawi. Tinggi tanaman dan panjang daun secara tunggal dipengaruhi oleh waktu aplikasi. Sumber bahan organik kotoran sapi dan jerami padi pada saat aplikasi 10 dan 15 hari sebelum penanaman bibit memberikan hasil terbaik pada jumlah daun, bobot segar sawi, N, P dan K.

Keywords: tanaman sawi, sumber bahan organik, waktu aplikasi, pupuk organik 


\section{PENDAHULUAN}

Sayuran sawi dibutuhkan setiap hari oleh pedagang makanan sebagai campuran menu makanan tertentu seperti bakso, sop, sayuran. Masyarakat secara umum menggemari sawi sebagai sayuran dan pelengkap sayuran serta sop. Sebab itu diperlukan teknik budidaya untuk meningkatkan hasil sayuran sawi.

Pemupukan merupakan salah satu alternatif pilihan petani dalam meningkatkan produksi pertanian. Petani sayuran sawi umumnya menggunakan pupuk anorganik seperti urea, $\mathrm{SP} 36, \mathrm{~K}_{2} \mathrm{O}$, dan pupuk majemuk seperti phonska. Pupuk kimia selain harganya relatif mahal juga sering susah diperoleh apalagi saat musim tanam tiba. Penggunaan pupuk organik merupakan alternatif pengganti pupuk kimia. Pupuk organik memegang peranan penting dalam sistem usahatani, karena kemampuannya dalam memperbaiki sifat fisik, kimia, dan biologi tanah. Penggunaan bahan-bahan organik akan menyehatkan tanah, menurunkan tingkat polusi dan limbah berbahaya sehingga tanah terlindung dari proses degradasi (Widyarti, 2009). Haryanto, dkk. (2006) mengatakan bahwa tanaman sawi membutuhkan pupuk kandang sebanyak 10 ton/ha. Penambahan bahan organik dengan cara pemberian pupuk organik secara kontinyu pada tanah merupakan cara pengelolaan yang murah dan mudah. Namun demikian, walaupun pemberian bahan organik pada lahan pertanian telah banyak dilakukan, umumnya produksi tanaman masih kurang optimal karena rendahnya unsur hara yang disediakan dalam waktu pendek serta rendahnya tingkat sinkronisasi antara waktu pelepasan unsur hara dari bahan organik dengan kebutuhan tanaman akan unsur hara. Kualitas bahan organik sangat menentukan kecepatan proses dekomposisi dan mineralisasi bahan organik.

Kotoran babi, sapi dan jerami padi merupakan limbah yang banyak ditemukan di daerah Minahasa dan sekitarnya. Limbah yang terbuang merupakan sumber bahan organik yang dapat digunakan sebagai pupuk organik. Limbah tersebut merupakan sumber hara apabila dikelola. Beberapa hasil penelitian mengindikasikan bahwa sebagian besar lahan pertanian intensif telah mengalami degradasi dan menurunnya produktivitas lahan, terutama terkait dengan sangat rendahnya kandungan C-organik. Bahan atau pupuk organik sangat bermanfaat bagi peningkatan produktivitas lahan pertanian dalam perbaikan sifat fisik, kimia dan biologi tanah, dan mengurangi pencemaran lingkungan. Pupuk organik mempunyai beragam jenis dan varian. Jenis-jenis pupuk organik dibedakan dari bahan baku, metode pembuatan dan wujudnya. Menurut Hadjowigeno (2003) jumlah pupuk yang diberikan berhubungan dengan kebutuhan tanaman akan unsur hara, kandungan unsur hara yang terkandung dalam tanah, serta kadar unsur hara yang terkandung dalam pupuk, sehingga apabila semua itu terpenuhi maka tanaman pun akan tumbuh baik dan memberikan hasil yang baik pula.

Penggunaan bahan organik pada media tanam jauh lebih unggul dibandingkan dengan pupuk anorganik. Namun masih banyak petani menggunakan pupuk anorganik pada lahan hortikultura seperti sawi. Hasil wawancara pada beberapa petani, mereka belum mengetahui pasti kapan waktu pemberian atau aplikasi pupuk organik sehingga hara yang dibutuhkan tanaman sesuai dengan stadia pertumbuhan tanaman. Apalagi bahan dasar pupuk organik bermacam-macam dengan ratio $\mathrm{C} / \mathrm{N}$ yang berbeda pula sehingga terjadi perbedaan waktu proses dekomposisi. Untuk itu petani perlu mengetahui kapan waktu pindah tanam bibit sawi setelah disemaikan.

Bahan organik mampu memperbaiki kondisi fisik, kimia dan biologi tanah, menghambat penguapan, memperkaya sistem enzim tanah serta memperbaiki pH tanah (Sutanto, 2002). Menurut Sutejo (2002), pupuk organik mempunyai fungsi yang penting dibandingkan dengan pupuk anorganik yaitu dapat menggemburkan lapisan permukaan tanah (topsoil), meningkatkan populasi jasad renik, mempertinggi daya serap dan daya simpan air, yang secara keseluruhan dapat meningkatkan kesuburan tanah. Pupuk organik dapat diperoleh dan atau dibuat dari berbagai sumber seperti sisa panen, sampah rumah tangga, kotoran hewan dan lain-lain. Menurut Kusuma (2012), salah satu alternatif pupuk kandang yang dapat digunakan adalah pupuk kandang kotoran sapi, 
kambing dan ayam. Selain kotoran hewan dari kandang, sisa jerami panen padi dapat dimanfaatkan sebagai sumber bahan organik. Jerami padi adalah limbah dari hasil panen tanaman padi yang mengandung lignoselulosa (hemesilulosa, selulosa, dan lignin). Selulosa adalah struktur karbohidrat yang berperan pada semua jenis tanaman.

Sumber bahan organik yang berbeda yaitu kotoran babi, sapi dan jerami padi dengan perbedaan waktu aplikasi diharapkan terjadi peningkatan pertumbuhan dan hasil sawi. Adapun tujuan penelitian untuk mempelajari interaksi sumber bahan organik dan waktu aplikasi guna meningkatkan pertumbuhan dan hasil sayuran sawi, mendapatkan sumber bahan organik dan waktu aplikasi yang tepat dalam meningkatkan pertumbuhan dan hasil sayuran sawi.

\section{METODE PENELITIAN}

Penelitian dilaksanakan di Kebun Percobaan Unsrat Kelurahan Wailan Tomohon, dan Laboratorium Jurusan Tanah Fakultas Pertanian Unsrat. Penelitian dilaksanakan sejak bulan Maret sampai Juli 2017.

Bahan dan alat yang digunakan adalah benih sawi, kotoran babi, kotoran sapi, jerami padi, EM4, gula pasir, air, sekam padi, dedak, media tanah, cangkul, sekop, ayakan, timbangan, plastik transparan, patok, paku, tali, pot plastic, tempat penampungan air, gembor, sprayer, alat tulis menulis, alat tulis kantor.

\section{Rancangan Percobaan}

Rancangan Acak Kelompok. Faktor pertama yang diteliti adalah : sumber bahan organik (A) terdiri dari: $\mathrm{A} 1=$ kotoran babi, $\mathrm{A} 2=$ kotoran sapi, $A 3=$ jerami padi. Faktor kedua adalah waktu aplikasi (B) Waktu: B1 $=5$ hari sebelum tanam bibit (SBTB), B2 $=10$ hari sebelum tanam bibit (SBTB), B3 $=15$ hari sebelum tanam bibit (SBTB). Setiap satuan percobaan diulang sebanyak tiga kali sehingga diperoleh 27 pot percobaan.

\section{Variabel Yang Diamati}

Variabel yang diamati adalah $\mathrm{N}, \mathrm{P}$, dan $\mathrm{K}$ di tanah sebelum penanaman dan setelah panen; Tinggi tanaman, jumlah daun, dan bobot basah Sawi, diamati pada akhir penelitian (panen).

Pengukuran bobot basah sawi dilakukan pada dua bagian tanaman yaitu a) akar, b) batang dan daun sawi.

\section{Analisis Data}

Data dianalisis menggunakan analisis ragam dan jika terdapat perbedaan dilanjutkan dengan Uji Beda Jujur (BNJ) pada taraf uji $5 \%$.

\section{Prosedur Kerja Penelitian \\ Persiapan Media Tanam}

Tanah diambil dari sekitar kebun, dibersihkan dari bebatuan, gulma dan kotoran lain. Tanah dikeringanginkan, dihaluskan, dan diayak kemudian dimasukkan ke dalam pot plastik dengan berat tanah $10 \mathrm{~kg}$ kering angin.

\section{Pembuatan Pupuk Kotoran Babi dan Sapi}

Kotoran babi diambil dari kandang kemudian dicampurkan dengan sekam, dedak (perbandingan 5:1:1), 1 liter EM4 dilarutkan dengan $1 \mathrm{~kg}$ gula aren. Semua bahan dicampur dibuat gundukan setinggi $50 \mathrm{~cm}$ kemudian ditutup dengan terpal. Suhu diamati setiap hari agar tidak melebihi $50^{\circ} \mathrm{C}$. Apabila panas adonan pupuk meningkat dilakukan pembongkaran adonan. Sepuluh hari pupuk siap diaplikasikan ke tanaman. Pembuatan pupuk kotoran sapi seperti pada kotoran babi.

\section{Pembuatan Pupuk Jerami Padi}

Jerami padi dicincang kurang lebih $5 \mathrm{~cm}$ kemudian dicampurkan dengan sekam, dedak, kotoran ayam (perbandingan 5:1:1:1), 1 liter EM4 dilarutkan dengan $1 \mathrm{~kg}$ gula aren.Semua bahan dicampur dibuat gundukan setinggi $50 \mathrm{~cm}$ kemudian ditutup dengan terpal. Suhu diamati setiap hari agar tidak melebihi $50^{\circ} \mathrm{C}$.Apabila panas adonan pupuk meningkat dilakukan pembongkaran adonan. Sepuluh hari pupuk siap diaplikasikan ke tanaman.

\section{Semai Benih}

Benih sawi dipilih diambil benih yang baik ditanam diatas bak penyemaian yang sudah diberikan tanah, kemudian dilapisi dengan tanah tipis. 
Penyiraman dilakukan pada kapasitas lapang, apabila bibit telah berdaun 5 , siap untuk dipindahkan ke pot penelitian.

\section{Penanaman}

Bibit sawi ditanam di pot plastik sebanyak 1 bibit per pot.

\section{Pemupukan}

Pemupukan dilakukan sesuai perlakuan yaitu waktu pemberian pupuk. Dosis pupuk organik untuk semua jenis pupuk (dari kotoran babi, kotoran sapi, dan jerami padi adalah 20 ton/ha).

\section{Pemeliharaan}

Penyiraman dilakukan apabila tidak ada hujan, sebanyak 1-2 kali sehari menggunakan gembor sampai pada kapasitas lapang. Penyulaman dilakukan jika ada tanaman yang mati.

\section{Panen}

Panen dilakukan setelah tanaman sawi berumur 50 hari setelah tanam.

\section{HASIL DAN PEMBAHASAN}

\section{Tinggi Tanaman dan Jumlah Daun Sawi}

Analisis statistik menunjukkan bahwa tinggi tanaman sawi tidak dipengaruhi oleh interaksi antara sumber bahan organik dan waktu aplikasi namun dipengaruhi oleh waktu aplikasi. Jumlah daun sawi dipengaruhi oleh interaksi antara sumber bahan organik dan waktu aplikasi. Hasil uji BNJ 5\% pada Tabel 1.

Tinggi tanaman sawi terbaik pada perlakuan waktu aplikasi bahan organik 15 hari sebelum tanam bibit. Waktu aplikasi bahan organik yaitu 15 hari sebelum pindah tanam bibit sawi menyebabkan bahan organik mengalami proses dekomposisi lebih lama dibandingkan 5 hari dan 10 hari sebelum pindah tanam bibit. Hakim, dkk. (1986) menyatakan proses dekomposisi yang terkandung dalam bahan organik akan menghasilkan nitrogen. Menurut Said (1996),dengan pengomposan maka bahan organik akan mengalami proses fermentasi dan dekomposisi sehingga nisbah $\mathrm{C} / \mathrm{N}$ mengalami perubahan yang mendekati nisbah $\mathrm{C} / \mathrm{N}$ tanah. $\mathrm{C} / \mathrm{N}$ bahan organik pada penelitian ini, sudah terdekomposisi dengan ratio C:N antara 13,89 sampai dengan 17,78 berarti $\mathrm{C} / \mathrm{N}$ ratio di bawah 20 sehinggaproses mineralisasi sudah terjadi. Apabila nisbah $\mathrm{C} / \mathrm{N}$ kompos mendekati nisbah $\mathrm{C} / \mathrm{N}$ tanah maka unsur hara yang terkandung dalam kompos akan mudah terserap oleh tanaman dan dapat memperbaiki serta mempertahankan kesuburan tanah, baik secara fisik, kimia maupun biologi (Effi, 2003). Senyawa nitrogen akan merangsang pertumbuhan vegetatif tanaman yaitu menambah panjang tanaman (Buckman dan Brady ,1982). Hal ini Nampak pada tinggi tanaman sawi perlakuan 15 hari sebelum pindah tanam bibit yaitu $24,10 \mathrm{~cm}$ yang berbeda dengan perlakuan 10 dan 5 hari sebelum tanam bibit. Nitrogen merupakan penyusun semua protein dan asam nukleat serta merupakan penyusun protoplasma secara keseluruhan. Nitrogen diserap tanaman dalam bentuk $\mathrm{NO}_{3}^{-}$(nitrat) dan $\mathrm{NH}_{4}{ }^{+}$(ammonium) berfungsi untuk menyusun khlorophyl, protoplasma, asam nukleat dan asam amino.

Tabel 1. Pengaruh Waktu Aplikasi Terhadap Tinggi Tanaman Sawi

(Table 1. Effect of Application Time on Plant Height)

\begin{tabular}{lc}
\hline \multicolumn{1}{c}{ Perlakuan } & Rata-rata Tinggi Tanaman (cm) \\
\hline B1 = 5 Hari Sebelum Tanam & $20,18 \mathrm{a}$ \\
B2 = 10 Hari Sebelum Tanam & $21,04 \mathrm{a}$ \\
B3 = 15 Hari Sebelum Tanam & $24,10 \mathrm{~b}$ \\
\hline BNJ 5\% & 2,50
\end{tabular}

Keterangan: Angka yang diikuti dengan huruf yang sama, tidak berbeda nyata berdasarkan uji BNJ pada taraf uji $5 \%$ 
Pengaruh interaksi antara sumber bahan organik dan waktu aplikasi terhadap jumlah daun terbaik pada perlakuan sumber bahan organik kotoran sapi pada 5 dan 10 hari sebelum pindah tanam bibi sawi yang tidak berbeda nyata dengan jerami padi 15 hari sebelum pindah tanam bibit sawi (Tabel 2 dan Gambar 1).

Tabel 2. Pengaruh Interaksi Sumber Bahan Organik dan Waktu Aplikasi Terhadap Jumlah Daun Tanaman Sawi

(Table 2. Effect of Interaction of Organic Source Material and Time of Application on Amount Leaf of Plant)

$\begin{array}{ll}\text { Perlakuan } & \text { Rata-rata Jumlah Daun Sawi }\end{array}$

\begin{tabular}{lc}
\hline A1B1 $=$ Kotoran Babi, 5 Hari Sebelum Tanam & $7,67 a$ \\
A1B2 $=$ Kotoran babi,10 Hari Sebelum Tanam & $9,67 a$ \\
A1B3 $=$ Kotoran Babi, 15 Hari Sebelum Tanam & $9,67 a$ \\
A2B1 $=$ Kotoran Sapi, 5 Hari Sebelum Tanam & $10,33 a b$ \\
A2B2 $=$ Kotoran Sapi,10 Hari Sebelum Tanam & $12,67 \mathrm{~b}$ \\
A2B3 $=$ Kotoran Sapi, 15 Hari Sebelum Tanam & $7,67 a$ \\
A3B1 $=$ Jerami Padi, 5 Hari Sebelum Tanam & $9,00 a$ \\
A3B2 $=$ Jerami Padi,10 Hari Sebelum Tanam & $9,33 a$ \\
A3B3 $=$ Jerami Padi,15 Hari Sebelum Tanam & $10,00 a b$
\end{tabular}

BNJ 5\%

2,72

Keterangan: Angka yang diikuti dengan huruf yang sama, tidak berbeda nyata berdasarkan uji BNJ pada taraf uji $5 \%$

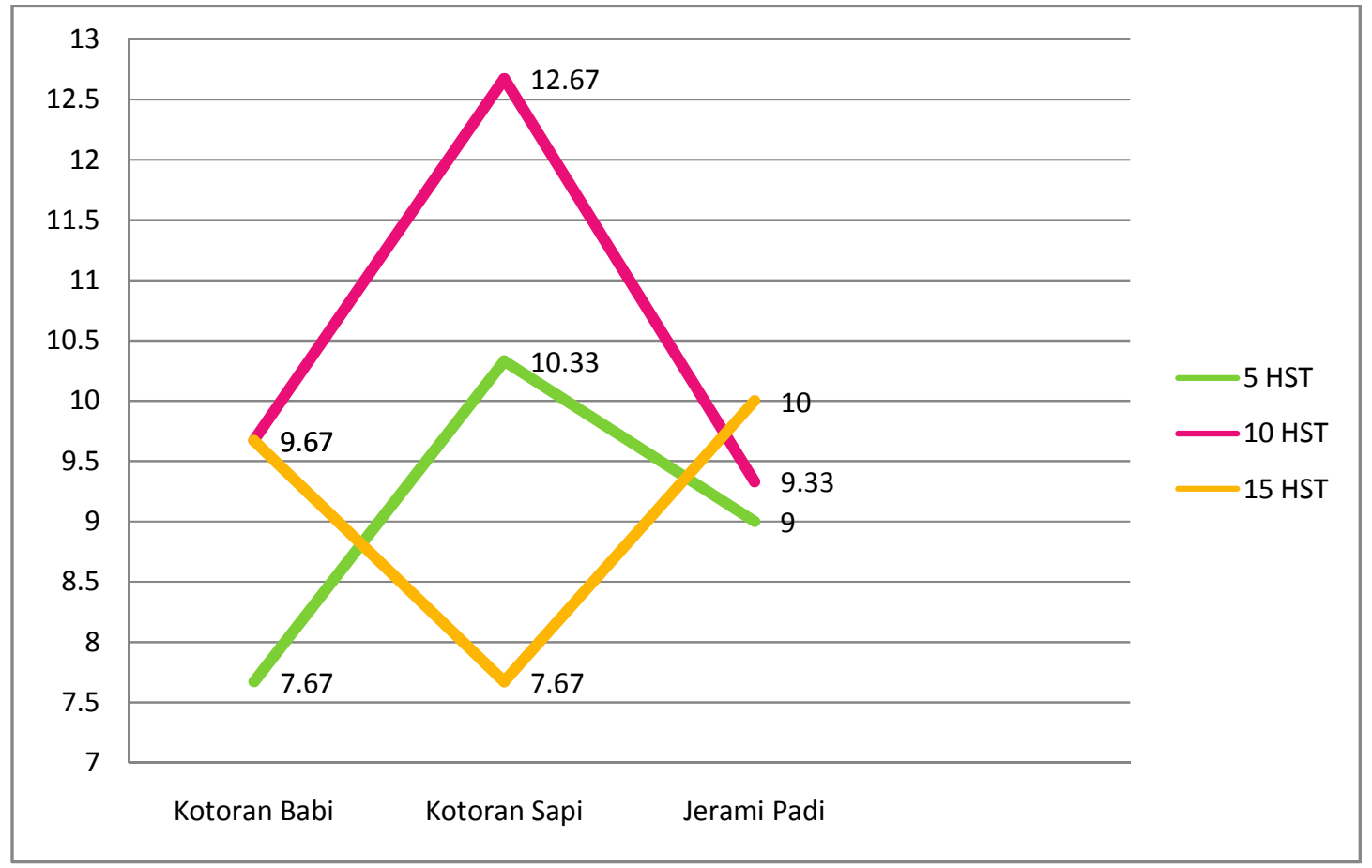

Gambar 1. Jumlah Daun Tanaman Sawi

(Figure 1. Number of Mustard Leaves ) 
Nitrogen berfungsi untuk meningkatkan pertumbuhan vegetatif, sehingga daun tanaman menjadi lebih lebar, berwarna lebih hijau dan lebih berkualitas (Wahyudi, 2010). Menurut Lingga (1991), kesuburan daun akan cepat berubah dan dapat menumbuhkan tunas baru karena dengan penyerapan hara $\mathrm{N}$, sehingga dapat meningkatkan pembentukan dan pertumbuhan daun pada tanaman. Kotoran sapi merupakan bahan organik secara spesifik berperan meningkatkan ketersediaan phosfor dan unsur-unsur mikro, mengurangi pengaruh buruk dari alumunium, menyediakan karbondioksida pada kanopi tanaman, terutama pada tanaman dengan kanopi lebat, dimana sirkulasi udara terbatas, kotoran sapi banyak mengandung hara yang dibutuhkah oleh tanaman seperti N, P, K, $\mathrm{Ca}, \mathrm{Mg}, \mathrm{S}$ dan B (Buckman, 1982). Hasil penelitian Sompotan (2012), menunjukkan bahwa pupuk kandang sapi tidak mempengaruhi pertumbuhan sawi tetapi mempengaruhi hasil sawi. Semakin tinggi dosis pupuk kandang sapi semakin tinggi bobot segar. Bahan organik jerami memberikan pengaruh yang sama dengan kotoran sapi terhadap jumlah daun sawi. Hasil analisis tanah menunjukkan bahwa kandungan $\mathrm{N}, \mathrm{P}$, dan $\mathrm{K}$ tanah setelah panen sawi lebih tinggi pada perlakuan kotoran sapi dan jerami padi pada 10 dan 15 hari sebelum pindah tanam bibit (Tabel 4). Penambahan bahan organik yang berasal dari sisa tanaman dan kotoran hewan selain menambah bahan organik tanah juga memberikan kontribusi terhadap ketersediaan hara N, P, dan K (Rachman, Djuniwati, dan Idris, 2008).

\section{Bobot Basah Sawi}

Analisis statistik menunjukkan bahwa bobot basah sawi dipengaruhi oleh interaksi antara sumber bahan organik dan waktu aplikasi. Hasil uji BNJ 5\% pada Tabel 3.

Pengaruh positif dari pemberian bahan organik seperti pupuk dari kotoran sapi terhadap pertumbuhan tanaman karena asam organik dengan berat molekul rendah, terutama bikarbonat hasil dekomposisi bahan organik dalam konsentrasi rendah dapat mempuyai sifat seperti senyawa perangsang tumbuh, sehingga berpengaruh positif terhadap pertumbuhan tanaman (Atmojo, 2003). Pemberian bahan organik pupuk kandang sapi akan menyebabkan $\mathrm{pH}$ meningkat, karena asamasam organik hasil dekomposisi akan meningkatkan Al membentuk senyawa kompleks (khelat) yang berguna dalam menunjang pertumbuhan tanaman sawi.

Tabel 3. Pengaruh Interaksi Sumber Bahan Organik dan Waktu Aplikasi Terhadap Bobot Basah Sawi (Table 3 Effect of Organic Source Interaction and Time of Application on Wet Weight)

Perlakuan

Rata-rata Bobot Basah Sawi (g)
$81,67 a$

$126,67 a b$

$144,00 \mathrm{~b}$

$146,67 \mathrm{~b}$

$166,00 \mathrm{~b}$

148,33 b

$143,33 \mathrm{~b}$

$153,33 \mathrm{~b}$

$146,00 \mathrm{~b}$

BNJ 5\% 47,21

Keterangan: Angka yang diikuti dengan huruf yang sama, tidak berbeda nyata berdasarkan uji BNJ pada taraf uji $5 \%$. 


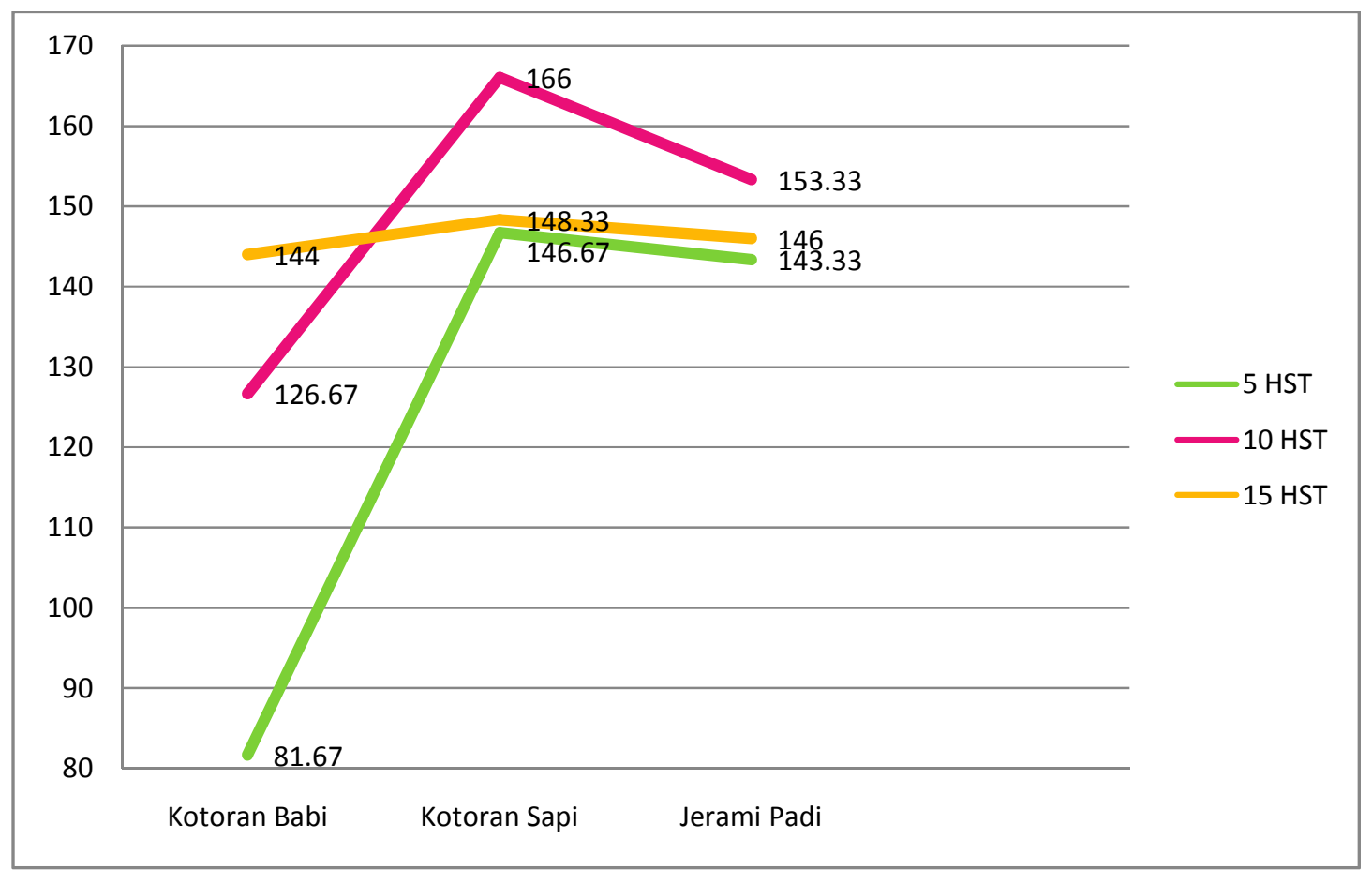

Gambar 2. Bobot Basah Sawi

(Figure 2. Wet Weights of Mustard)

Menurut Hadisumitro (2002), bahwa pupuk kandang sapi merupakan pupuk kandang baik untuk memperbaiki kesuburan, sifat fisika, kimia dan biologi tanah, meningkatkan unsur hara makro dan mikro, meningkatkan daya pegang air dan meningkatkan kapasitas tukar kation. Pupuk dari kotoran sapi mengandung hara makro N, P, dan $\mathrm{K}$ disamping hara mikro lainnya. Unsur hara $\mathrm{N}$ berfungsi sebagai perangsang pertumbuhan tanaman secara keseluruhan, khususnya batang, cabang dan daun (Hakim, dkk., 1986). Sementara unsur $P$ berfungsi memacu pertumbuhan akar dan pembentukan sistem perakaran yang baik sehingga tanaman dapat mengambil unsur hara lebih banyak dan pertumbuhan tanaman menjadi sehat serta kuat. Sama seperti yang diungkapkan oleh Thompson dan Troeh (1978), bahwa fosfat dibutuhkan oleh tanaman untuk pembentukan sel pada jaringan akar dan tunas yang sedang tumbuh. Sedangkan unsur $\mathrm{K}$ menurut pendapat
Setyamidjaya (1996), berfungsi untuk mengaktifkan enzim-enzim yang mempercepat pertumbuhan jaringan meristimatik. Meningkatnya kalium yang dapat diserap tanaman mengakibatkan pertumbuhan jaringan meristimatik akan lebih baik. Menurut Dwijosapoetro (1986), penambahan unsur $\mathrm{N}$ dalam tanah dapat meningkatkan hasil bobot brangkasan basah, selain itu juga mampu meningkatkan pertumbuhan akar, batang dan daun sehingga bobot brangkasan basah naik.

Sumber bahan organik meningkatkan kandungan $\mathrm{N}, \mathrm{P}$, dan $\mathrm{K}$ tanah setelah penelitian. Sumber bahan organik jerami padi dan kotoran sapi yang telah diproses menjadi pupuk organik meningkatkan kesuburan tanah. Menurut Sutedjo (2010), bahwa pupuk kandang dapat dianggap sebagai pupuk yang lengkap, karena selain menghasilkan hara yang tersedia juga meningkatkan aktivitas mikroorganisme didalam tanah. 
Tabel 4. Pengaruh Interaksi Sumber Bahan Organik dan Waktu Aplikasi Terhadap Kandungan N, P, dan K Tanah Setelah Panen Sawi

(Table 4. Effect of Interaction of Organic Matter Source and Time of Application on Content N, P, and K Soil After Harvest)

\begin{tabular}{llcc}
\hline \multicolumn{1}{c}{ Perlakuan } & K Tanah & $\begin{array}{c}\text { Kandungan } \\
\text { P Tanah }\end{array}$ & K Tanah \\
\hline A1B1 = Kotoran Babi, 5 Hari STBT & $0,1267 \mathrm{a}$ & $10,78^{\mathrm{a}}$ & $16,07 \mathrm{e}$ \\
$\mathrm{A} 1 \mathrm{~B} 2$ = Kotoran babi,10 Hari STBT & $0,1467 \mathrm{a}$ & $11,38 \mathrm{c}$ & $14,62 \mathrm{~b}$ \\
A1B3 = Kotoran Babi,15 Hari STBT & $0,1333 \mathrm{a}$ & $12,19 \mathrm{~d}$ & $15,99 \mathrm{de}$ \\
A2B1 = Kotoran Sapi, 5 Hari STBT & $0,1300 \mathrm{a}$ & $11,04 \mathrm{~b}$ & $12,64 \mathrm{a}$ \\
A2B2 = Kotoran Sapi,10 Hari STBT & $0,1600 \mathrm{~b}$ & $13,35 \mathrm{f}$ & $17,44 \mathrm{f}$ \\
A2B3 = Kotoran Sapi,15 Hari STBT & $0,1333 \mathrm{a}$ & $11,10 \mathrm{~b}$ & $18,92 \mathrm{~h}$ \\
A3B1 = Jerami Padi, 5 Hari STBT & $0,1367 \mathrm{a}$ & $17,43 \mathrm{~h}$ & $15,66 \mathrm{~cd}$ \\
A3B2 = Jerami Padi,10 Hari STBT & $0,1400 \mathrm{ab}$ & $12,52 \mathrm{e}$ & $15,37 \mathrm{c}$ \\
A3B3 = Jerami Padi,15 Hari STBT & $0,1400 \mathrm{ab}$ & $13,96 \mathrm{~g}$ & $18,30 \mathrm{~g}$ \\
\hline BNJ 5\% & 0,0205 & 0,25 & 0,39
\end{tabular}

Keterangan: Angka yang diikuti dengan huruf yang sama, tidak berbeda nyata berdasarkan uji BNJ pada taraf uji $5 \%$.

\section{KESIMPULAN}

Pengaruh interaksi antara sumber bahan organik dengan waktu aplikasi yang berbeda nyata terhadap jumlah daun, bobot segar, kandungan $\mathrm{N}$, $\mathrm{P}$, dan $\mathrm{K}$ tanah setelah panen sawi. Tinggi tanaman sawi dan panjang daun secara tunggal dipengaruhi oleh waktu aplikasi.

Sumber bahan organik kotoran sapi dan jerami padi pada waktu aplikasi 10 dan 15 hari sebelum tanam bibit memberikan hasil terbaik pada jumlah daun, bobot segar sawi, kandungan $\mathrm{N}, \mathrm{P}$, dan $\mathrm{K}$.

\section{DAFTAR PUSTAKA}

Atmojo, S.W. 2003. Peranan Bahan Organik terhadap Kesuburan Tanah dan Upaya Pengelolaannya. Pidato Pengukuhan Guru Besar IImu Kesuburan Tanah. Fakultas Pertanian Universitas Sebelas Maret. Surakarta.
Buckman dan Brady. 1982. IImu Tanah. Terjemahan Prof. Dr. Soegiman. Penerbit Bhratara Karya Aksara. Jakarta.

Dwijosapoetra, D. 1986. Pengantar Fisiologi Tumbuhan. Gramedia. Jakarta.

Effi, I.M. 2003. Pupuk Organik; Cair dan Padat. Aplikasi Penebar Swadaya. Jakarta.

Hadisumitro, L.M. 2002. Membuat Kompos. Jakarta. Penebar Swadaya, 54 hal.

Hakim, N.M.A., M. Nyakpa, S. G. Lubis, Nugroho, M. Saul, A. Diha, G.B. Hong dan H.H. Bailey. 1986. Dasar-Dasar IImu Tanah. Universitas Lampung. Lampung.

Hardjowigeno, S. 2003. IImu Tanah. Akademia Presindo, Jakarta.

Haryanto, B., T. Suhartini, E. Rahayu dan Sunarjo. 2006. Sawi dan Selada. Penebar Swadaya. Jakarta 
Kusuma, M.E. 2012. Pengaruh Beberapa Jenis Pupuk Kandang terhadap Kualitas Bokashi. Jurnal Hewani Tropika, 1 (2): 4146.

Lingga, P. 1991. Kotoran Ternak Penyubur Tanah. Jakarta: Penebar Swadaya.

Rachman, I.A., S. Djuniwati dan K. Idris. 2008. Pengaruh Bahan Organik dan Pupuk NPK Terhadap Serapan Hara dan Produksi Jagung di Inceptisol Ternate. J. Tanah Lingk. 10(1):7-13.

Sutedjo. 2002. Pemberian Pupuk Kandang. diunduh pada balit tanah. Litbang.deptan. go.id (Diakse tanggal 5 Pebruari 2015).

Said, G. 1996. Penanganan dan Pemanfaatan Limbah Kelapa Sawit. Trubus Agriwidya. Ungaran.

Setyamidjaja, D. 1986. Pupuk dan Pemupukan. Penerbit CV Simplek. Jakarta.

Sompotan, S. 2012. Role of Organic Matter in Mitigation of Pesticides on Cabbage (Brassica oleracea L.) Cropping. (Asian Transactions on Basic and Applied Sciences (ATBAS ISSN: 2221-4291) Volume 02 Issue 05. Bulletin Palma (Bulletin of Palmae) Vol. 13 No.1, Juni 2012. ISSN 1979-679X.
Sompotan, S. 2013. Hasil Tanaman Sawi (Brassica Juncea L.) Terhadap Pemupukan Organik dan Anorganik. Geosains Volume 2, Nomor 1, J uni 2013 Halaman: 14-17. ISSN: 2252- 8717 .

Sutanto, R. 2002. Penerapan Pertanian Organik, Pemasyarakatan dan Pengembangannya. Kanisius Yogyakarta.

Thompson, L.M. and F.R. Troeh. 1978. Soils \& Soil Fertility. McGraw-Hill Pub. xi $+516 \mathrm{~h}$.

Tan, K.H. 1993. Principles of Soil Chemistry. Marcel Dekker, Inc. New York. 362pp.

Wahyudi. 2010. Petunjuk Praktis Bertanam Sayuran. Agromedia Pustaka. Jakarta

Widyarti, B. 2009. Hidup Organik, Panduan Ringkas Berperilaku Selaras Alam. Aliansi Organis Indonesia. Bogor. 